\title{
A tudásgazdaság jellemzői Magyarország vonatkozásában
}

\section{Characteristics of knowledge economy in respect of hungary}

\author{
J. T. KISS \\ Debreceni Egyetem, Műszaki Kar, tkis@t-online.hu
}

Absztrakt. Az utóbbi évtizedekben egyre inkább elötérbe került az információ, a tudás, valamint az emberi tőke és az emberi tőkébe történő beruházás gazdaságbeli szerepének a vizsgálata. Az elemzések kiterjednek a tudásgazdaság jellemzésére, valamint a piaci kihívások vizsgálatára. A tanulmányban arra keressük a választ, hogy hogyan adható meg a tudásgazdaság meghatározása, melyek a tudásgazdaság mérésre alkalmazható indikátorok, továbbá hogy mi jellemzi Magyarországot egy-egy indikátor vonatkozásában.

Abstract. The examination of the economic role of information, knowledge, human capital and investment into the human capital has come into the limelight over the last decades. Analyses include the characterisation of knowledge economy and the relationship between knowledge economy and market challenges. In this paper we examine the definition and indicators of knowledge-based economy. We analyse the trend of the participation rate in formal and non-formal education as a knowledge input, furthermore we examine the gross domestic expenditure on $R \& D$ as a percentage of GDP with particular attention to Hungary.

\section{Bevezetés}

Az utóbbi évtizedekben egyre inkább előtérbe került az információ, a tudás, valamint az emberi tőke gazdaságbeli szerepének a hangsúlyozása, akár vállalati szinten a termelés növelése, akár egy nemzetgazdaság gazdasági növekedésének a vonatkozásában. A gazdasági növekedés vizsgálatával foglalkozó kutatók már az 1960-as évek közepétől kezdve elemezték a hagyományos termelési tényezők (azaz a munka és a tőke) mellett, a humán tőke és a kutatás-fejlesztés hatását a gazdasági növekedésre nézve (Nelson - Phelps, 1966; Lucas, 1988; Romer, 1990; Becker - Murphy - Tamura, 1990; Rebelo, 1991). A vizsgálatok során, a kutatók többek között arra keresték a választ, hogy van-e befolyásoló ereje a humán tőkének egy nemzetgazdaság gazdasági növekedésében, és ha igen, akkor vajon a meglévő humántőke-szintje, azaz annak a nagysága, vagy a humántőke-állományának a változása lehet hatással a gazdasági növekedésre nézve. Egy-egy nemzetgazdaság vonatkozásában régóta és egyben sokat hangoztatott fogalom a tudásgazdaság, tudásalapú-gazdaság, tanuló-gazdaság, valamint az információgazdaság. 
Felmerül a kérdés, hogy: Mit értünk tudásgazdaság alatt, vajon a tudásgazdaság, tanuló-gazdaság és az információgazdaság ugyanazt jelenti, vagy jelentős eltérés van az említett fogalmak között? Továbbá, mi alapján dönthetjük el, hogy mely országban alakult már ki a tudásgazdaság, és melyikben nem, azaz léteznek-e olyan mutatók, amelyek alapján megállapítható, hogy egy nemzetgazdaság milyen mértékben tekinthető tudásgazdaságnak. A dolgozatban arra keressük a választ, hogy hogyan adható meg a tudásgazdaság meghatározása, valamint melyek azok a mutatók, amelyek alkalmasak a tudásgazdaság mérésére, azaz amelyek segítségével mérhetjük a tudásgazdaság előrehaladásának a mértékét, továbbá megvizsgáljuk, hogy Magyarország hogyan jellemezhető a tudásgazdaság bizonyos indikátorainak a tükrében.

\section{A tudásgazdaság fogalmi megközelítése, értelmezése}

A tudásgazdaság, vagy a tudásalapú-gazdaság és az információgazdaság elnevezéseket rendszerint egymás szinonimáiként alkalmazzák. A tudásgazdaság fogalmát Peter Drucker vezette be az elsők között 1969-ben, aki a The Age of Discontinuity" című könyvében külön fejezetet is szentelt a tudásgazdaság ismertetésének (The Knowledge Economy). Az 1900-as évek Amerikájában a munkavállalók elsősorban vidékiek voltak, farmokon éltek, azonban 1940-re a legnagyobb arányuk már ipari munkavállaló volt, akik elsősorban betanított munkásokat vagy képezetlen gépkezelő munkaerőket jelentettek. 1960-ban már a szakképzett vezetők és a műszaki szakemberek aránya volt a nagyobb, őket Drucker (1969) ún. tudás munkavállalóknak (knowledge worker) nevezett, akik iránti igény Drucker véleménye szerint kielégíthetetlen, és akik egyben jobban is fizetettek voltak a többi munkavállalóhoz képest. Drucker (1969) szerint a tudás lett a gazdaság központi költsége. Drucker (1969) alapján nemcsak a munka jellege, a foglalkoztatottak minősítése változott meg, hanem a termelés és a szolgáltatás jellege is, ami azt jelenti, hogy egyre inkább előtérbe kerültek a hagyományos értelembe vett szolgáltatások és javak előállítása helyett az elképzelések és az információk biztosítása.

Az OECD 1996-ban adta közre „A tudásalapú gazdaság” című írását, amely alapján a tudásalapú gazdaság a tudás és az információ termelésén, elosztásán, és felhasználásán alapul. A gazdaságbeli teljesítményhez elengedhetetlen a tudásba történő beruházás és a tudás elosztása akár formális akár informális hálózatokon keresztül. A tudás egyre inkább számítógépeken és kommunikációs hálózatokon keresztül testesül meg és terjed a feltörekvő információs társadalomban. A tudásalapú gazdaságban folytonos tanulás szükséges, ahol az innovációt elsősorban a termelők és a felhasználók kapcsolatán keresztül cserélődő megtestesült és rejtett tudás eredményezi (OECD, 1996). A foglalkoztatottakra jellemző, hogy növekszik a magasan képzett munkavállalók iránti kereslet. A technológiai változások és az információs technológia megjelenése eredményezi, hogy egyre értékesebb a tanult és a szakképzett munkaerő, míg a képzetlen munkaerő pedig egyre kevésbé. Az oktatás lesz a tudásalapú gazdaság központi eleme, és a tanulás az egyéni és a szervezeti fejlődés eszköze (OECD, 1996:14), azonban a tanulás nem csupán a formális oktatás keretei között megy végbe, ugyanis a learning by doing, azaz a munka közbeni tanulás szerepe is kimagasló.

Smith (2002) egyik tanulmányában a tudásgazdaság meghatározásának a szükségességét vetette fel, mert véleménye szerint maga a fogalom már egyre inkább, mint egy sokat hangoztatott jelző jelenik 
meg korunk fejlett társadalmaira, miközben mögötte tényleges tartalom nem jelenik meg. Smith (2002) írásában többek között arra kereste a választ, hogy hogyan adható meg a tudásgazdaság meghatározása. Smith kritikával illette az OECD (1996) tanulmányában közreadott meghatározást, ugyanis az nagyon jól tükrözi a fogalom használata során felmerülő problémát, azaz véleménye szerint maga a meghatározás lefed mindent és egyben semmit se. Felmerül a kérdés, hogy a tudás milyen értelmezését tekintjük, mint pl. ismeretelméleti (episztemológiai) megközelítést vagy kognitív értelmezését. Smith (2002) alapján a tudásgazdaságnak 4 megközelítése létezik a szakirodalomban, melyek a következőek:

- Az első megközelítés a tudás, mint termelési tényező fontosságát hangsúlyozza, amely a többi termelési tényezőhöz képest (természeti erőforrások, tőke, alacsony képzettséget igényelő vagy képzetlen munka) jelentősen felértékelődött, azaz mind mennyiségében és minőségében is sokkal fontosabb tényező, mint bármely input valaha.

- A második megközelítés alapján a tudás fontosabb, mint bármely termék korábban, a tudás, mint termék kereskedelme alapján új tevékenységi formák terjednek el.

- A harmadik megközelítés a kodifikált tudás jelentőségét hangsúlyozza, szemben a tacit tudással, az egyénekben megtestesült képességekkel.

- Végül, a negyedik megközelítés alapján a tudásgazdaság az információs-kommunikációs technológiában bekövetkező technológiai változásokon alapul. Az információs és kommunikációs technológiai rendszerek olyan új és különböző technológiai alapot adnak, amelyek radikális változásokat eredményeznek a termelés feltételeiben és a tudás eloszlásában.

Az átalakulás jelei, a tudásalapú-gazdaság főbb ismérvei többek között a következőek:

- Nő a magasan képzett munkavállalók iránti kereslet.

- Szoros együttműködés, valamint a tudás és az információ cseréje jellemzi a termelők és a felhasználók közötti kapcsolatot, mindez hozzájárul az innovációhoz.

- A kutató laboratóriumoknak és a felsőoktatási intézményeknek kulcsfontosságú a szerepe a tudás létrehozásában, valamint annak továbbításában, átadásában. A kutatóintézetek és a felsőoktatás egyre inkább teremt kapcsolatot az ipari szereplőkkel, mind finanszírozási, mind innovációs célokból.

- Jelentősen nő a csúcstechnológiájú iparágak termelése és foglalkoztatása, amitől a tudásintenzív szolgáltatási szektor (oktatási, kommunikációs és információs szektor) térnyerése az erősebb.

- Megváltoznak az innovációs folyamatok, a hagyományos lineáris folyamat (kutatás-fejlesztés termelés - piaci bevezetés) sokkal összetettebb, hálószerű szerkezetet követ. Az innováció esetében együttműködés jellemzi a vállalatokat, kutatóintézeteket, fogyasztókat, felhasználókat, tervezőket. Átalakul a kutatás-fejlesztés finanszírozási struktúrája, amely hozzájárul a pénzügyi és egyéb kockázatoknak a megosztásához, esetleges csökkentéséhez.

\section{A tudásalapú-gazdaság jellemzésére alkalmazható mutatók áttekintése}

Felvetődik a kérdés, hogy a hagyományos ipari társadalmakban alkalmazott gazdasági mutatók megállják-e a helyüket a tudásalapú-gazdaságban is, vagy esetleg új indikátorok bevezetésére van szükség. A kérdés tárgyalása azért is fontos, mert ha a hagyományosan alkalmazott mutatók nem 
adnak teljes képet egy gazdaság teljesítményéről, teljesítőképességéről, akkor azok használata nem nyújt megfelelő alapot a kormány és a gazdaság szereplőinek a döntéséhez, a kialakításra kerülő politikákhoz, amelyek a megfelelő megalapozottság hiánya miatt téves útra is vezethetnek.

Az OECD (1996) által a tudásalapú-gazdaság mérésre bevezetett mutatói a következő öt csoportra oszthatóak:

- a tudás-inputok (kutatás-fejlesztésre fordított kiadások, a foglalkoztatott mérnökök és műszaki személyzet aránya, szabadalmak, a technológia nemzetközi fizetési mérlege);

- a tudásállománya és a tudás szintje (a technológia intenzitása, információs technológia elterjedése);

- tudás-outputok (kutatás-fejlesztés intenzitása, amely megmutatja a kutatás-fejlesztésre fordított kiadásoknak a GDP-hez viszonyított arányát, a kutatás-fejlesztés intenzitásának szektorok szerinti alakulása);

- tudáshálózatok (a tudás és az innováció terjedése a gazdaságban, a vállalatok innovációs hajlandósága, vállalatok együttmúködése, és egyben kutatóintézetek, egyetemek, az állam és az ipar együttmúködése a tudástranszfer elérése érdekében);

- tudás és tanulás (a tanulás egyéni és társadalmi megtérülése, a munka közbeni képzés megtérülése, a kutatás-fejlesztés egyéni és társadalmi megtérülése).

A tudásgazdaság gazdasági környezete jelentős kihívásokat támaszt a gazdasági szereplők elé. Az innovációk egyre sűrűbben valósulnak meg, amelyek a gazdasági előrehaladás fő tényezőivé válhatnak. A gazdaság azáltal, hogy globálissá vált, megemelkedett a versenytársak száma, valamint az innovációk okozta változások folyamatos alkalmazkodást követelnek a gazdaság szereplőitől (Hámori - Szabó, 2011). A változásokhoz való alkalmazkodás egyik fontos tényezője a rugalmasság, a versenyben maradáshoz rugalmasság jellemezte szervezetekre, termelésre, munkapiaci szerkezetekre van szükség. Továbbá a gazdaság aktív szereplőinek folyamatos tanulásra, azaz ún. élethosszig történő tanulásra kell elkötelezni magukat, ahhoz hogy a szüntelenül változó és egyben megújuló gazdasági, termelési környezetben helyt tudjanak állni.

Magyarország vonatkozásában Hámori - Szabó (2011) vizsgálta, hogy Magyarország hol helyezkedik el az információgazdaság fő meghatározó tényezőjének az innováció vonatkozásában. Vizsgálataik eredménye alapján arra a következtetésre jutottak (a 2000-es évek közepéig vizsgált adatok alapján), hogy nemzetközi összehasonlításban gyengék a tudásvezérelt információgazdaság felé mutató trendek (Hámori - Szabó, 2011).

A Világbank létrehozta a tudásgazdaság (Knowledge Economy Index - KEI) indexet, amely egy ország vagy régió tudásgazdaságbeli versenyképességének a mérésére alkalmazható. A mutató méri, hogy mennyire hatékonyak a gazdaságok az új és a meglévő tudás hasznosítására a gazdasági és társadalmi fejlődés vonatkozásában. A KEI mint aggregált mutató négy indikátor átlagaként adható meg, amelyek rendre a következőek (Chen - Dahlman, 2005; Worldbank, 2016):

- A gazdasági és intézményi rendszer jellemzője, azaz azok mennyire ösztönzik az új és a meglévő tudás hatékony felhasználását (vámjellegű akadályok, szabályozások minősége, jogállamiság). 
- Tanult és képzett népesség aránya, akik folyamatosan aktualizálják tudásukat, és egyben alkalmasak új tudást létrehozni, megosztani, valamint megfelelő módon felhasználni (oktatási évek száma, felsőfokú oktatásba és a középiskolákba beiratkozottak aránya).

- A vállalatok, kutatóintézetek, egyetemek, szaktanácsadók és egyéb szervezetek hatékony innovációs rendszere, amelyhez tartozik a globális tudásállományából való elsajátításának jellemzői, a helyi igényeknek megfelelő adaptációja és új technológia létrehozása (szabadalmak, tudományos és múszaki folyóiratcikkek).

- Az információs, kommunikációs technológia jellemezői, amely lehetővé teszi az információ és a tudás hatékony létrehozását, közzétételét, feldolgozását (a mutatók közzé tartozik többek között a telefonok, számítógépek valamint az internetet alkalmazók 1000 főre jutó száma).

A következőkben arra keressük a választ, hogy a tudásgazdaság jelentette kihívások ernyője alatt hogyan alakult az élethosszig tartó tanulás Magyarországon, megtörtént-e a tanulási szakasz kitolódása, valamint arra, hogy hogyan alakult a kutatás-fejlesztésre fordított kiadások mértéke Magyarországon, mint a tudás egyik input tényezőjének a nagysága az Európai Uniós országok összehasonlításában.

\section{Az élethosszig tartó tanulás főbb jellemzői Magyarországon}

Az élethosszig tartó tanulás keretében az új tudás elsajátításának időszak egyre inkább kitolódott a tudásgazdaságokban. A következőkben megvizsgáljuk, hogy hogyan alakult a felsőoktatásba jelentkezők száma, valamint azt, hogy a formális oktatáson túl a nem formális képzést mi jellemzi Magyarországon, nevezetesen valóban bővült-e a nem formális oktatásban résztvevők száma és annak életkor szerinti megoszlása.

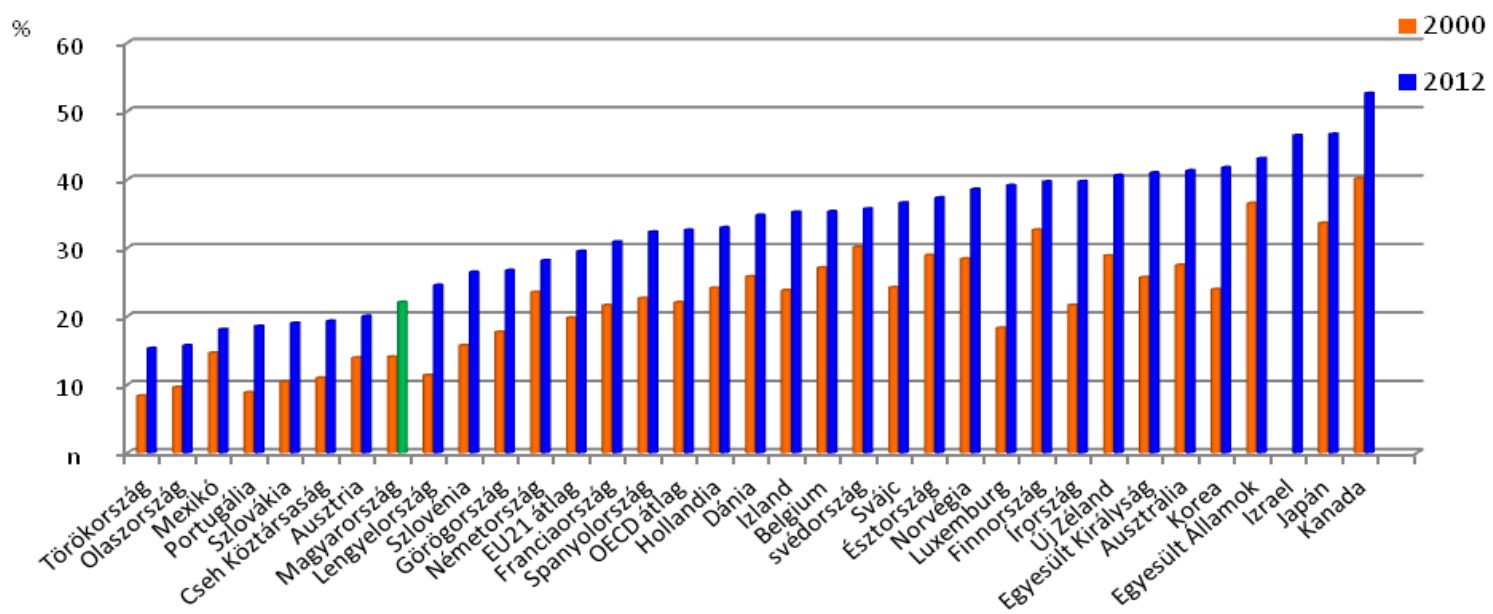

1. ábra A felsőfokú végzettséggel rendelkezők aránya a 25-64 éves korcsoporton belül, 2000. és 2012. év (\%)

(Forrás: Eurostat, 2015)

A felsőfokú végzettséggel rendelkezők aránya a 25-64 éves korcsoporton belül Kanadában (53\%), Japánban (47\%) és Izraelben (46\%) a legmagasabb, ugyanakkor több országban éri el még az említett arány a viszonylag magas 40\% fölötti értéket. A felsőfokú végzettségűek aránya Törökországban (15\%), Olaszországban (16\%) és Mexikóban (17\%) volt a legkisebb (2012. év). Az Európai Unióra 
vonatkozó átlag mértéke 29\%, amelytől Magyarország 7 százalékponttal (22\%) maradt el 2012-ben. Valójában Magyarország az alacsony értékekkel rendelkező országok közé tartozik, többek között Szlovákiával (19\%) és a Cseh Köztársasággal együtt (19\%). A felsőfokú végzettséggel rendelkezők aránya a 25 és 64 évvel rendelkezőkhöz viszonyítva annak ellenére alacsony Magyarországon, hogy a kilencvenes évektől megindult a hallgatói létszám növekedése, különösen a kilencves évek közepétől, tekintettel arra, hogy az előző évhez viszonyított növekedési ráta elérte az 1994/1995 tanévben a 17,6\%-ot, 1997/1998 tanévben a 18,4\%-ot (1. táblázat). A hallgatói létszám a 2006/2007-es tanévtől fokozatosan csökkeni kezdett, tanévtől függően $0,4 \%$ és $5,9 \%$ közötti értékkel. A felsőfokú végzettséggel rendelkezők arányának nemzetközi összehasonlításában, a figyelembe vett 33 ország közül (amelyekre az adatok elérhetőek voltak) Magyarország a 8. legkisebb értékkel rendelkezik, azaz a tudásgazdaságra vonatkozó magas humán tőke szint nem jellemzi az országot.

\begin{tabular}{|l|l|l|l|}
\hline Tanév & $\begin{array}{l}\text { Hallgató } \\
\text { létszám } \\
\text { változása } \\
\text { (előző év= } \\
100 \%)\end{array}$ & Tanév & $\begin{array}{l}\text { Hallgató } \\
\text { létszám } \\
\text { változása } \\
\text { (előző év= } \\
100 \% \text { ) }\end{array}$ \\
\hline $1992 / 1993$ & 9,8 & $2004 / 2005$ & 3,0 \\
\hline $1993 / 1994$ & 14,8 & $2005 / 2006$ & 0,6 \\
\hline $1994 / 1995$ & 17,6 & $2006 / 2007$ & $-1,8$ \\
\hline $1995 / 1996$ & 15,1 & $2007 / 2008$ & $-4,5$ \\
\hline $1996 / 1997$ & 10,0 & $2008 / 2009$ & $-4,2$ \\
\hline $1997 / 1998$ & 18,4 & $2009 / 2010$ & $-2,8$ \\
\hline $1998 / 1999$ & 9,7 & $2010 / 2011$ & $-2,4$ \\
\hline $1999 / 2000$ & 9,4 & $2011 / 2012$ & $-0,4$ \\
\hline $2000 / 2001$ & 7,1 & $2012 / 2013$ & $-5,9$ \\
\hline $2001 / 2002$ & 6,7 & $2013 / 2014$ & $-5,4$ \\
\hline $2002 / 2003$ & 9,2 & $2014 / 2015$ & $-4,2$ \\
\hline $2003 / 2004$ & 7,2 & & \\
\hline
\end{tabular}

1. táblázat. A felsőfokú oktatásban tanuló hallgatói létszám változása az előző évhez képest az 1992/1993 tanév és a 2014/2015 tanév között

(Forrás: KSH, 2015)

A nem formális keretek között végbemenő oktatás és képzés ad legtöbbször lehetőséget az élethosszig tartó tanulás megvalósítására, különösen az idősebb korosztály számára. A informális oktatás minden olyan képzés, amely kiszorul az oktatási rendszerbe illeszkedő képzésekből. Legtöbbször tanfolyamok, munkáltató által biztosított és szervezett, vagy oktatási cég által szervezett munka közbeni képzéseket 
jelent. Az 55-64 évesek aránya a nem formális oktatásban való részvételt tekintve a 25-64 éves korcsoport létszámához viszonyítva valójában négy kategóriába sorolható, nevezetesen a 10\% alatt, a 10 és 25\% közötti, a 25 és 40\% közötti valamint a 40\% feletti értékkel rendelkezőkre (2.ábra).

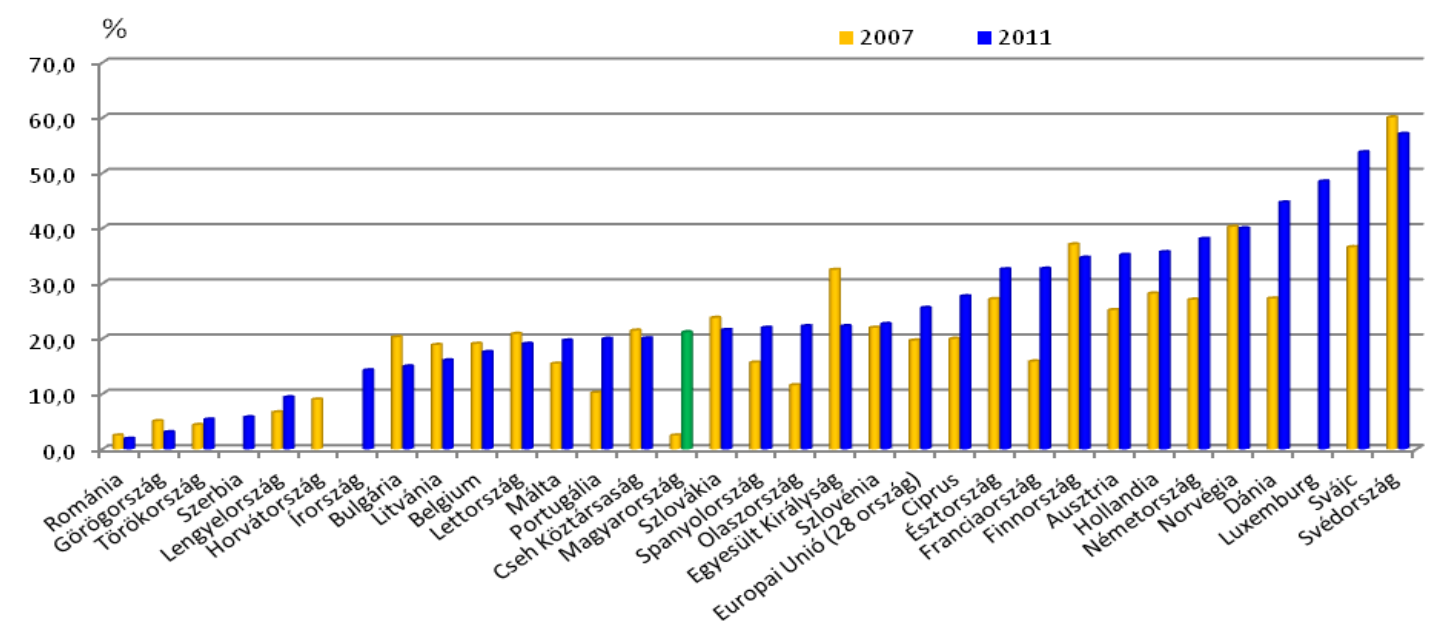

2. ábra Az 55-64 éves korcsoport nem formális oktatásban tanulók aránya a korcsoport százalékában, 2007. és 2011. év (\%)

(Forrás: Eurostat, 2015)

Kimagaslóan magas aránnyal rendelkezett Svédország (57,1\%) és Svájc (53,8\%) 2011-ben, ugyanakkor a legalacsonyabb értékekkel bírt Románia és Görögország rendre 1,9\% és 3,1\%-os rátával. Magyarország a 10\% és 25\% közötti értékekkel jellemezhető országok csoportjába tartozott a 21,2\%os arányával, ezen csoportoz tartozott a megfigyelt országok 43,8\%-a (2. ábra). Ugyanakkor a 35-44 és a 45-54 éves korcsoport informális képzésben való részvételi aránya jelentősen emelkedett rendre 34,7 és 34, 3 százalékponttal Magyarországon a 2007. és a 2011 év időszak alatt. Mindez azt jelenti, hogy 2011-ben az említett két korcsoportból 43,3\% és 41,1\% vett rész valamilyen nem formális képzésben a 25-64 éves korcsoport arányához viszonyítva (Eurostat, 2015, 2. táblázat). A formális és a nem formális képzések vonatkozásában a 25-64 évesek közül 2011-ben 41,1\% vett rész valamilyen képzésben, amely jelentős elmozdulás a 2007. évre jellemző 9,1\%-os arányról (Eurostat, 2015, 2. táblázat).

Magyarország az egyetlen olyan ország a vizsgált OECD országok közül, ahol az informális képzésben résztvevők arányában a legnagyobb mértékű emelkedés következett be valamennyi korcsoport vonatkozásában a 2007. évről a 2011. évre. Az informális oktatásbeli részvétel ilyen nagyarányú emelkedése azt jelenti, hogy a piac rugalmasan reagált a kihívásokra, azaz Magyarországon jelentős alkalmazkodás következhetett be mint az oktatási piac és mind a munkapiac oldaláról. Ugyanakkor a nagyarányú emelkedés ellenére sem mondhatjuk, hogy Magyarország az informális képzésben részvevők arányával az élenjáró országok közé tartozna, tekintettel arra, hogy a változás nagyon alacsony részvételi arányról következett be (2. táblázat, 3. táblázat).

\begin{tabular}{|l|l|l|l|}
\hline formális oktatás (\%) & $\begin{array}{l}\text { nem formális } \\
\text { oktatás (\%) }\end{array}$ & $\begin{array}{l}\text { formális és nem } \\
\text { formális oktatás }\end{array}$ \\
\hline
\end{tabular}


2. táblázat. A formális és a nem formális oktatásban tanulók korcsoportonként aránya a 25 és 64 éves népességhez viszonyítva és összesen, Magyarország

(Forrás: Eurostat, 2015)

\begin{tabular}{|l|l|l|l|l|l|l|}
\hline & \multicolumn{2}{|l|}{ formális oktatás } & \multicolumn{2}{l|}{ nem formális } & \multicolumn{2}{l|}{ együtt } \\
\hline & 2007 & 2011 & 2007 & 2011 & 2007 & 2011 \\
\hline $25-34$ & 14,2 & 13,6 & 36,1 & 40,8 & 44,1 & 48,5 \\
\hline $35-44$ & 5,8 & 6 & 35,4 & 40,7 & 38,5 & 44 \\
\hline $45-54$ & 3,8 & 3,7 & 31,6 & 38,8 & 33,5 & 40,9 \\
\hline $55-64$ & 2 & 1,6 & & & 20,8 & 26,6 \\
\hline Összesen & 6,6 & 6,2 & 31,2 & 36,8 & 34,8 & 40,3 \\
\hline
\end{tabular}

3. táblázat. A formális és a nem formális oktatásban tanulók korcsoportonként aránya a 25 és 64 éves népességhez viszonyítva és összesen, Európai Unió átlag

(Forrás: Eurostat, 2015)

A formális és az informális oktatásban való részvételi arányt, mint a tanulás, az oktatás mérőszámát követően, tekintsük át a kutatás-fejlesztésre fordított kiadások alakulását, amely egyfajta tudás inputként adható meg.

\section{A kutatás-fejlesztésre fordított kiadások alakulása Magyarországon}

Magyarországon a hazai kutatás-fejlesztésre fordított bruttó kiadások mértéke a GDP százalékában 0,97\%-ról 1,38\%-ra emelkedett 2007 és 2014 év között (3. ábra). Az említett érték az Európai Unió országai tekintetében a középmezőnyben található ugyanis az országokra vonatkozó arányok 0,38\% és 3,17 \% között alakultak 2014-ben, míg az Európai Uniós átlag mértéke 2,03\% volt (Eurostat, 2016a, 3. ábra). A vizsgált időszak alatt Magyarországon következett be a legmagasabb mértékű emelkedés (0,41 százalékponttal), igaz a kezdeti időszakra vonatkozó érték igen alacsony volt, de voltak olyan 
országok ahol csökkent a vizsgált ráta nagysága (mint Finnország, Izland, Luxemburg, Románia, Svédország és Spanyolország esetében).

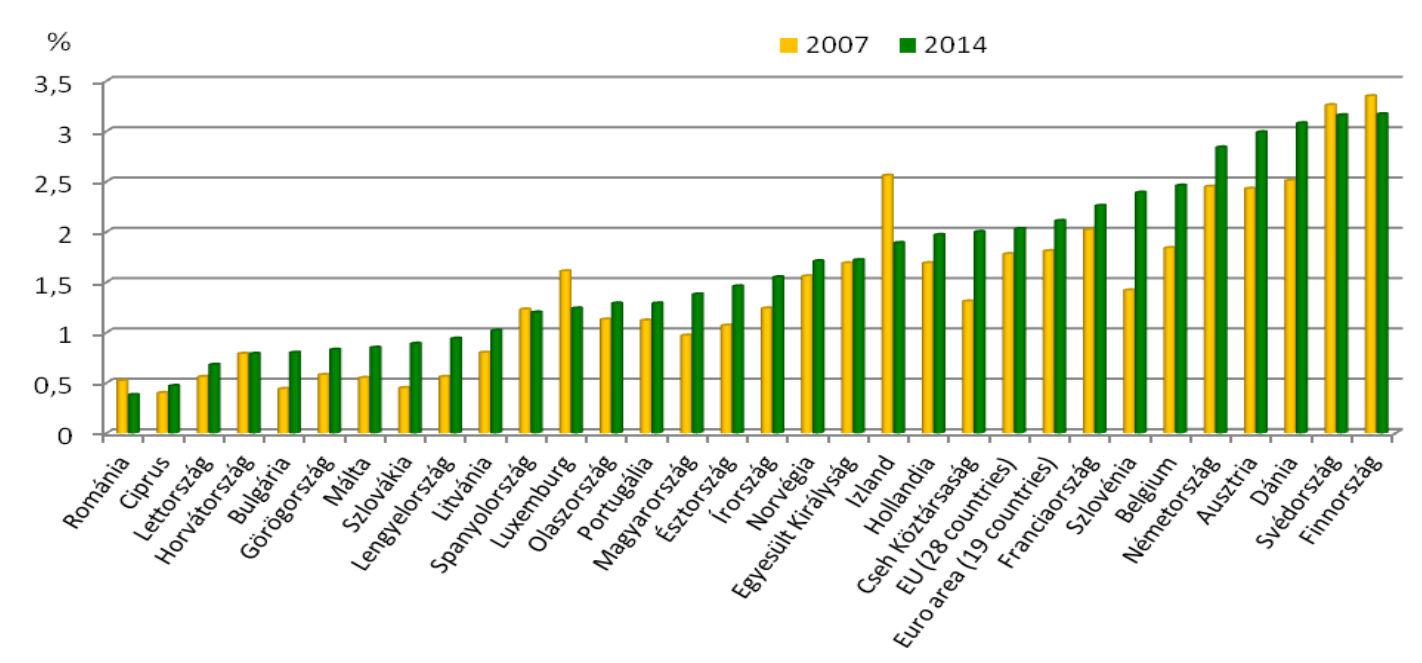

3. ábra A kutatás-fejlesztésre fordított kiadások mértéke a GDP százalékában, 2007. és 2014. év

(Forrás: Eurostat, 2016a)

A tudás generálásának, termelésének a folyamatában meghatározó lehet az állami szerepvállalás jellege, azaz, hogy ösztönző esetlegesen ellenösztönző hatással bír-e a gazdasági szereplők tudásberuházással kapcsolatos döntéseire nézve. Továbbiakban megvizsgáljuk az állam kutatásfejlesztésre fordított kiadásainak alakulását a költségvetési kiadások százalékában megadva.

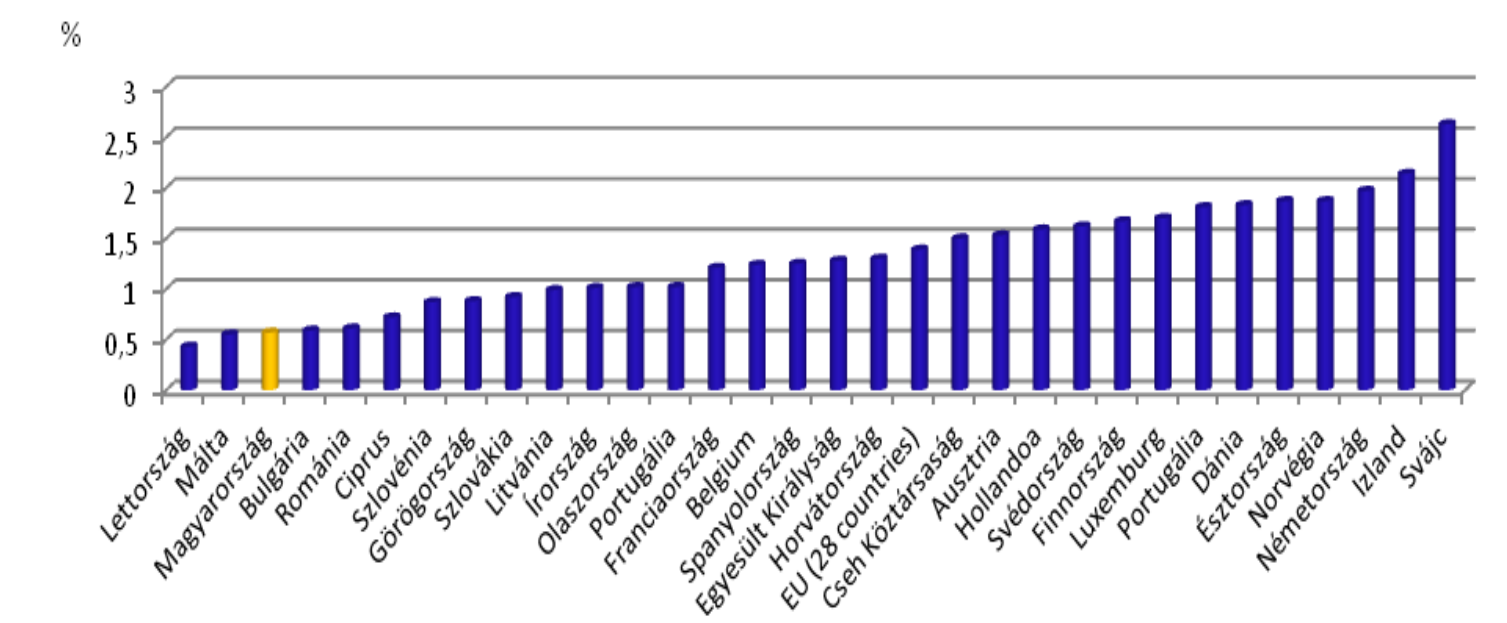

4. ábra Az állam kutatás-fejlesztésre fordított kiadásainak mértéke a teljes költségvetési kiadások százalékában, 2014. év

(Forrás: Eurostat, 2016b)

Az állam kutatás-fejlesztésre fordított kiadásainak mértéke az Európai Uniós országok körében 0,43\% és 2,63\% között alakult 2014-ben. A legnagyobb arányt felmutató országokhoz tartozott Svájc (2,63\%), Izland (2,14\%), Németország (1,97\%), Norvégia (1,87\%) és Észtország (1,87\%), míg az Európai Uniós átlag 1,39\% volt. Magyarország bírt a harmadik legkisebb értékkel a teljes költségvetési 
kiadásokhoz viszonyított kutatás-fejlesztésre fordított kiadások tekintetében 2014-ben (0,57 százalékkal). A bolgár és román értékektől is elmaradó magyar arány nem volt még ilyen alacsony az elmúlt 10 évre visszetkintve, mint 2014-ben.

\section{6. Összefoglalás}

Az utóbbi évtizedekben egyre inkább előtérbe került az információ és a tudás generálásának, elsajátításának, valamint megosztásának gazdaságbeli hatásának a vizsgálata. Az OECD 1996-ban adta közre „A tudásalapú gazdaság” című kötetét, amely alapján a tudásalapú gazdaság a tudás és az információ termelésén, elosztásán, és felhasználásán alapul, és amely alapján a gazdaságbeli teljesítményhez elengedhetetlen a tudásba történő beruházás és a tudás megosztása, átadása akár formális akár informális hálózatokon keresztül. A tanulmányban a tudásgazdaság meghatározásán túl, arra kerestük a választ, hogy melyek a tudásgazdaság mérésére, leírására alkalmas indikátorok, mutatók, valamint, hogy hogyan jellemezhető Magyarország egy-két indikátor tekintetében.

A vizsgálatok során arra a következtetésre jutottunk, hogy a felsőoktatás hallgatói létszámának a jelentős emelkedése ellenére Magyarország a felsőfokú végzettséggel rendelkezőknek a 25-64 éves korcsoport arányához viszonyítva az Európai Uniós országok tekintetében még az átlagtól is jelentősen elmarad, hiszen míg az uniós átlag 29\% volt 2012-ben, addig a magyar arány 22\% volt. Ugyanakkor jelentős emelkedés mutatható ki az informális oktatásbeli részvételi arányt tekintve. Az informális oktatásbeli részvétel nagyarányú emelkedése azt jelenti, hogy a piac rugalmasan reagált a kihívásokra, azaz Magyarországon jelentős alkalmazkodás következhetett be mint az oktatási piac és mind a munkapiac oldaláról.

A kutatás-fejlesztésre fordított kiadásoknak a GDP arányában vizsgált mutatója alapján is elmarad Magyarország az uniós átlagtól, hiszen míg az átlagos érték 1,78\% volt 2014-ben, addig a magyar adat 0,98\% volt. Még jelentősebb az elmaradás ha az állam kutatás-fejlesztésre fordított kiadásainak a mértékét vizsgáljuk a teljes költségvetési kiadások arányában. A magyar arány 0,57\% volt szemben az Európai Unió átlagával, amely 1,38\% volt 2014-ben.

A tanulmányban vizsgált uniós átlagtól elmaradó arányok ellenére megállapítható, hogy Magyarországon a legtöbb indikátor értékében jelentős emelkedés mutatható ki az elmúlt évekhez viszonyítva, ami azt jelenti, hogy Magyarország is reagál a tudást előtérbe helyező piaci kihívásokra, azonban a jelenlegi elmaradás oka részben a kezdeti elmaradás mértékével, azaz azzal magyarázható, hogy az emelkedés más országokhoz viszonyítva lényegesen alacsonyabb értékről indult.

\section{Hivatkozások}

[1] G. S. Becker, K. M. Murphy, R. Tamura (1990), Human Capital, Fertility, and Economic Growth, The Journal of Political Economy, Vol. 98, No. 5, Part 2: The Problem of Development: A Conference of the Institute for the Study of Free Enterprises Systems, S12S37. 
[2] D. H. C. Chen, C. J. Dahlman (2005), The Knowledge Economy, the KAM Methodology and World Bank Operations, The World Bank Washington DC 20433.

[3] P. Drucker (1969), The Age of Discontinuity: Guidelines to Our Changing Society, William Heinemann Ltd. London.

[4] Eurostat (2015), Participation rate in education and training by age, http://appsso.eurostat.ec.europa.eu/nui/show.do Letöltés ideje:2016.02.21.17.49.

[5] Eurostat (2016a), Gross Domestic Expenditure on $R \& D$, http://ec.europa.eu/eurostat/tgm/table.do?tab=table\&init=1\&plugin=1\&language=en\&pc ode=t2020_20. Letöltés ideje:2016.02.22.18.10.

[6] Eurostat (2016b), Share of government budget appropriations or outlays on research and development,

http://ec.europa.eu/eurostat/tgm/table.do?tab=table\&init=1\&plugin=1\&language=en\&pc ode=tsc0000. Letöltés ideje: 2016.01.2 10.08.

[7] B. Hámori, K. Szabó K. (2011), A rendszerváltás féloldalassága - A gyenge innovációs teljesítmény magyarázatához, Egyenlítő, Társadalomkritikai és Kulturális Folyóirat, 2011/1. http://egyenlito.eu/category/lapszamok/69-szam/. letöltés ideje: 2015. 08. 10. 11.25 .

[8] KSH (2015), Felsőfokú hallgatói létszám, http://www.ksh.hu/docs/hun/xstadat/xstadat_eves/i_zoi007a.html. Letöltés ideje: 2015. 09. 02.15 .32

[9] R. E. Lucas (1988), On the Mechanics of Economic Development, Journal of Monetary Economics, Vol. 22, 3-42.

[10] R. R. Nelson, E. S. Phelps (1966), Investment in Humans, Technological Diffusion, and Economic Growth, The American Economic Review, Vol. 56, No. 1/2. 69-75.

[11] OECD (1996), The Knowledge-based Economy, OCDE/GD(96)102, Paris

[12] P. M. Romer (1990), Endogenous Technological Change. The Journal of Political Economy, Vol. 98, No. 5, Part 2: The Problem of Development: A Conference of the Institute for the Study of Free Enterprise Systems, S71-S102.

[13] S. Rebelo (1991), Long-Run Policy Analysis and Long-Run Growth, The Journal of Political Economy, Vol. 99, No. 3, (Jun., 1991), pp. 500-521.

[14] K. Smith (2002), What is the knowledge Economy? Knowledge intensity and distributed knowledge bases, The United Nations University, Institute for New Technologies, Discussion Paper Series 2002/6, ISSN: 1564-8370.

[15] Worldbank (2016), Measuring Knowledge in the World's Economies. Knowledge assessment Methodology and Knowledge Economy Index, The Worldbank Institute, http://siteresources.worldbank.org/INTUNIKAM/Resources/KAMbooklet.pdf. Letöltés ideje: 2016. 02. 2419.02. 